\title{
Distribusi Kemampuan Berpikir Matematik Tingkat Tinggi pada Siswa Sekolah Menengah Atas Kota Tasikmalaya Tahun Pelajaran 2018/2019
}

\author{
Depi Ardian Nugraha ${ }^{1, *}$, Satya Santika ${ }^{2}$ \\ ${ }_{1,2}$ Universitas Siliwangi \\ *depi@unsil.ac.id
}

\begin{tabular}{|l|l|l|}
\hline Received : 28-12-2019 & Revised: $31-3-2020$ & Accepted: $1-4-2020$ \\
\hline
\end{tabular}

\begin{abstract}
ABSTRAK
Penelitian ini bertujun untuk mengetahui distribusi kemampuan berpikir matematik tingkat tinggi (Higher Order Mathematical Thinking Skills/HOTS) siswa dan mengetahui hubungan antara kemampuan berpikir kritis matematis dengan berpikir kreatif matematis siswa SMAN di Kota Tasikmalaya tahun pelajaran 2018/2019. Penelitian ini menggunakan metode deskriptif kuantitatif dengan populasi seluruh siswa SMAN Kota Tasikmalaya pada kisaran usia 16-18 tahun. Teknik pengambilan sampel menggunakan proportionate stratified random sampling, dan terpilih dua kelas setiap sekolah. Instrumen penelitian menggunakan soal tes kemampuan berpikir matematik tingkat tinggi yang merupakan irisan dari dimensi kognitif Taksonomi Bloom dengan dimensi Pengatahuan Kurikulum 2013 dan terdiri dari soal kemampuan berpikir kritis dan kreatif. Hasil penelitian menunjukkan bahwa kemampuan HOTS matematika dari seluruh siswa di SMAN seKota Tasikmalaya, 20\% siswa di antaranya berada pada kategori sangat baik, $70 \%$ siswa berada pada kategori baik, dan $10 \%$ siswa lainnya berada pada kategori cukup baik. Di samping itu dapat disimpulkan pula bahwa $8 \%$ kemampuan berpikir kritis matematis berhubungan secara signifikan dengan kemampuan berpikir kreatif matematik siswa SMAN di Kota Tasikmalaya tahun pelajaran 2018/2019.
\end{abstract}

Kata Kunci: Higher Order Mathematical Thinking Skills, kemampuan berpikir kritis matematik, kemampuan berpikir kreatif matematik

\begin{abstract}
This study aims to determine the distribution of students' higher order mathematical thinking skills (HOTS) and to know the relationship between mathematical critical thinking abilities and mathematical creative thinking of high school students in Tasikmalaya City in 2018/2019. This study uses a quantitative descriptive method with a population of all students of Tasikmalaya City High School in the age range of 16-18 years. The sampling technique uses proportionate stratified random sampling, and two classes are selected for each school. The research instrument used high-level mathematical thinking ability test questions which are slices of the cognitive dimension of Bloom's Taxonomy with the 2013 Curriculum Dimension dimension and consisted of critical and creative thinking skills. The results showed that the HOTS mathematical ability of all students in high schools in Tasikmalaya City, 20\% of students were in the very good category, $70 \%$ of students were in the good category, and $10 \%$ of the other students were in the quite good category. In addition, it can also be concluded that $8 \%$ of mathematical critical thinking skills are significantly related to the mathematical creative thinking abilities of high school students in the City of Tasikmalaya in the 2018/2019 academic year.
\end{abstract}

Keywords: Higher Order Mathematical Thinking Skills, Mathematical Critical Thinking Skills, Mathematical Creative Thinking Skills. 


\section{PENDAHULUAN}

Lahirnya era revolusi industri 4.0 dan society 5.0 menjadi tantangan yang sangat berat bagi semua lapisan masyarakat Indonesia pada berbagai dimensi kehidupan. Berbagai permasalahanpun muncul, misalnya adalah persaingan untuk memperoleh kesempatan terbaik dalam berbagai hal, tidak hanya secara lokal atau nasional, melainkan dalam skala yang lebih luas dan terbuka lagi hingga menembus batas-batas teritorial negara. Upaya untuk menghadapi tantangan dan perkembangan abad modern ini, yang diperlukan bukan sekedar pengetahuan konseptual semata, melainkan keterampilan mengaplikasikan pengetahuan dan berbagai keterampilan berpikir lainnya. Terkait dengan hal tersebut, Partnership for 21st Century Skills (2002) merumuskan beberapa keterampilan yang selanjutnya disebut sebagai kecakapan abad 21 atau sering disebut 21st Century Skills. Beberapa keterampilan yang termuat dalam kecakapan abad 21 tersebut diantaranya yaitu kreativitas, keterampilan berpikir kritis dan pemecahan masalah. Keterampilanketerampilan tersebut sering juga dikenal sebagai cakupan dari keterampilan berpikir tingkat tinggi. Tuntutan akan perlunya keterampilan-keterampilan tersebut berimplikasi pada perlunya peningkatan kualitas penyelenggaraan pendidikan.

Upaya peningkatan kualitas penyelenggaran pendidikan di berbagai Negara termasuk di Indonesia, ditandai dengan adanya reformasi kurikulum, termasuk kurikulum matematika. Sebagai contoh, di Amerika Serikat kurikulum matematika untuk sekolah menengah secara eksplisit telah memuat pemecahan masalah, penalaran, komunikasi, koneksi, dan representasi sebagai bagian dari cakupan kurikulum (NCTM, 2000). Begitupun dengan Finlandia yang menempatkan keterampilan berpikir tingkat tinggi sebagai bagian dari kurikulum sekolah menengah, yaitu melalui muatan kurikulum "keterampilan berpikir dan metode berpikir" (thinking skills and methods) (Finish National Agency for Educaition, 2003). Di Indonesia muatan kurikulum yang berorientasi pada pengembangan berbagai keterampilan berpikir, khususnya keterampilan berpikir tingkat tinggi mulai diperhatikan dengan diterapkannya Kurikulum 2013. Oleh karena itu keterampilan berpikir tingkat tinggi atau higher order thinking skills (HOTS) menjadi tujuan utama dalam proses pembelajaran, termasuk pembelajaran matematika.

Berbicara mengenai tujuan pembelajaran, dalam dunia pendidikan hal tersebut biasanya mengacu kepada taksonomi (hierarki berpikir) tujuan pembelajaran. Salah satu taksonomi yang paling terkenal yaitu taksonomi Bloom yang dikemukakan oleh Benjamin S. Bloom pada tahun 1956. Jika dikaitkan dengan proses kognitif dalam taksonomi Bloom tersebut, istilah HOTS sering dikontraskan dengan istilah LOTS (Lower Order Thinking Skills). Proses kognitif analisis (analysis), sintesis (synthesis), dan evaluasi (evaluation) 
dikategorikan sebagai HOTS, sedangkan pengetahuan (knowledge), pemahaman (comprehension), dan aplikasi (application) dikategorikan sebagai LOTS (Fisher, 2006, p. 375). Masih terkait pengkategorian HOTS dan LOTS dalam taksonomi Bloom, pendapat berbeda dikemukakan oleh (Thompson, 2008, p. 3) yang mengategorikan analisis, sintesis, dan evaluasi sebagai HOTS, pengetahuan dan pemahaman sebagai LOTS, sedangkan aplikasi masuk kategori HOTS atau LOTS.

Setelah taksonomi Bloom direvisi oleh Anderson et al. (2001), dimana tujuan pembelajaran dibagi menjadi dua dimensi yaitu proses kognitif dan pengetahuan, maka HOTS dalam taksonomi Bloom perlu dilakukan penyesuaian. Adapun jika dikaitkan dengan taksonomi Bloom revisi yang dikemukakan oleh Anderson et al. (Anderson et al., 2001), pada dimensi proses kognitif HOTS meliputi proses menganalisis (analyze), mengevaluasi (evaluate), dan mencipta (create) (Liu, 2009), sedangkan pada dimensi pengetahuan HOTS meliputi pengetahuan konseptual (conceptual knowledge), pengetahuan prosedural (procedural knowledge), dan pengetahuan metakognitif (metacognitive knowledge). Adapun klasifikasi HOTS pada masing-masing dimensi dalam taksonomi Bloom revisi dapat dilihat pada Tabel 1.

Tabel 1. HOTS dalam Taksonomi Bloom Revisi

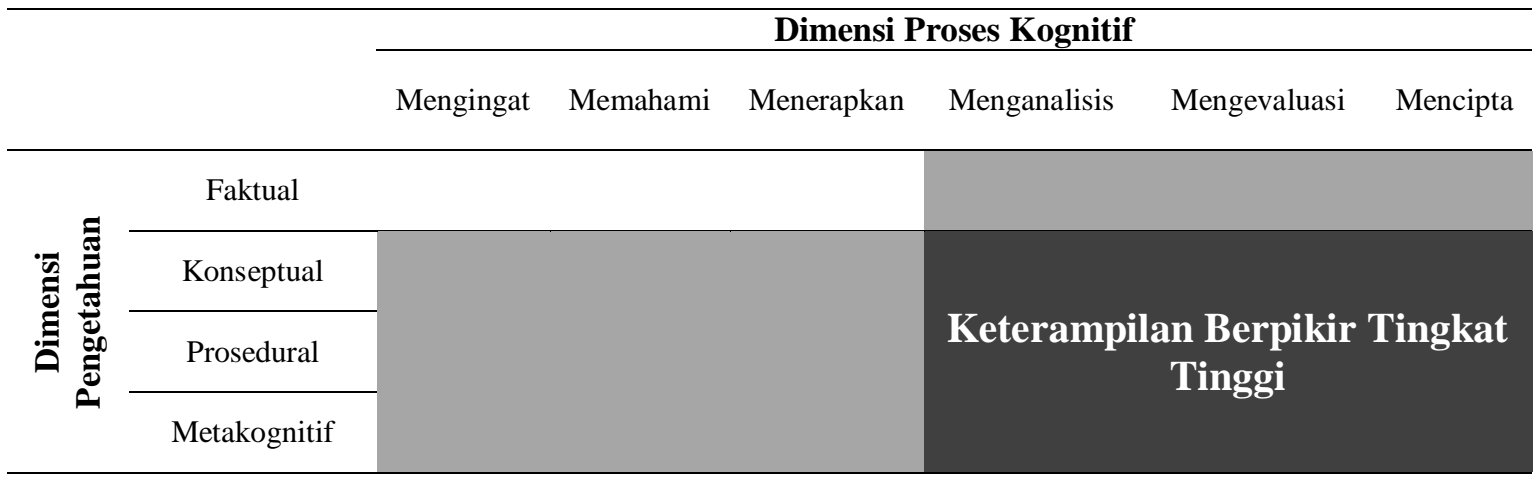

Mengacu kepada Tabel 1, dapat dipahami bahwa pengkategorian HOTS yang lebih modern tidak lagi hanya melibatkan satu dimensi (dimensi proses kognitif saja), tetapi HOTS merupakan irisan antara tiga komponen dimensi proses kognitif teratas (menganalisis, mengevaluasi, dan mencipta) dan tiga komponen dimensi pengetahuan tertinggi (konseptual, prosedural, dan metakognitif). Dengan kata lain indikator pembelajaran di luar irisan tersebut dalam taksonomi Bloom revisi tidak dapat dianggap sebagai HOTS. Sebagai contoh, indikator pembelajaran yang memuat proses kognitif mengevalusi (memeriksa, mengkritisi), tetapi pada dimensi pengetahuan berada pada level faktual (penggunaan lambang, simbol, notasi), bukan merupakan indikator dari HOTS. Hal tersebut karena level faktual pada dimensi pengetahuan tidak termasuk bagian dari HOTS. 
Kita telah memahami bahwa HOTS paling mudah diidentifikasi melalui taksonomi Bloom. Dengan adanya taksonomi Bloom revisi yang dikemukan oleh Anderson et al. (Anderson et al., 2001), kita dapat dengan mudah merumuskan indikator HOTS dalam pembelajaran. Dalam taksonomi Bloom revisi tersebut, dimensi proses kognitif dipandang sebagai kata kerja (verb) yang berfungsi untuk menggambarkan proses tertentu, sedangkan dimensi pengetahuan dipandang sebagai kata benda (noun) yang berfungsi sebagai objek dari proses yang dilakukan. Adanya kedua komponen tersebut (verb dan noun) menjadi alasan mengapa merumuskan indikator dalam taksonomi Bloom revisi menjadi lebih mudah.

Apabila kita cermati kembali terkait proses kognitif yang masuk kategori HOTS yaitu menganalisis, mengevaluasi, dan mencipta, maka kita dapat mengkategorikan bahwa menganalisis dan mengevaluasi merupakan bagian dari berpikir kritis, sedangkan mencipta merupakan bagian dari berpikir kreatif. Menganalisis dan mengevaluasi merupakan bagian dari berpikir kritis didasarkan pada penjabaran definisi berpikir kritis yaitu sebagai proses melakukan penilaian berdasarkan bukti (Eggen \& Kauchak, 2012), menganalisis argumen, mengenali kesenjangan, dan menyimpulkan berdasarkan bukti (Arends \& Kilcher, 2010). Sedangkan mencipta dapat dianggap sebagai bagian dari berpikir kreatif sesuai dengan pendapat para ahli bahwa berpikir kreatif merupakan proses untuk menghasilkan produk/ide/sesuatu yang baru (Arends \& Kilcher, 2010; Krulik \& Rudnick, 1999; Presseisen, 2001). Dengan demikian jika kita buat keterkaitan antara aspek berpikir kritis dan kreatif, dimensi proses kognitif, dan dimensi pengetahuan, maka dapat disimpulkan bahwa HOTS dalam pembelajaran matematika meliputi kemampuan berpikir kritis matematik dan kemampuan berpikir kreatif matematik.

Penelitian yang mengukur, mendeskripsikan mengembangkan keterampilan berpikir matematik tingkat tinggi telah dilaksanakan Hidayati (2017), Agustyaningrum (2015), serta Somatanaya dan Nugraha (2018). Penelitian ini sedikit berbeda dengan penelitian yang telah dilakukan oleh beberapa peneliti, dimana pada penelitian ini kemampuan berpikir matematik tingkat tinggi yang dimaksud adalah irisan dari dimensi kognitif taksonomi Bloom dengan dimensi pengetahuan tertinggi pada Kurikulum 2013 di Indonesia, dimana pada dimensi proses kognitif ada tahapan menganalisis, mengevaluasi dan mencipta sedangkan pada dimensi pengetahuan ada proses konseptual, prosedural dan metakognitif, dimana apabila kuda hal tersebut saling beririsan maka akan mendekati indikator dari kemampuan berpikir kritis dan kreatif matematik, dimana kedua kemampuan ini memiliki ciri berpikir non-prosedural yang antara lain mencakup hal-hal berikut: 1) kemampuan mencari dan mengeksplorasi pola untuk memahami struktur matematik serta 
hubungan yang mendasarinya; 2) kemampuan menggunakan fakta-fakta yang tersedia secara efektif dan tepat untuk memformulasikan serta menyelesaikan masalah; 3) kemampuan membuat ide-ide matematik secara bermakna; 4) kemampuan berpikir dan bernalar secara fleksibel melalui penyusunan konjektur, 5) generalisasi, dan jastifikasi; 6) serta kemampuan menetapkan bahwa suatu hasil pemecahan masalah bersifat masuk akal atau logis.

Berdasarkan hal tersebut maka tujuan penelitian ini adalah: 1) untuk mengetahui bagaimana distribusi Kemampuan Berpikir Matematik Tingkat Tinggi (HOTS) pada Siswa Sekolah Menengah Atas Negeri Kota Tasikmalaya Tahun Pelajaran 2018/2019, dan 2) untuk mengetahui apakah terdapat hubungan antara kemampuan berpikir kritis matematis dengan kemampuan berpikir kreatif matematika siswa Sekolah Menengah Atas Negeri di Kota Tasikmalaya tahun pelajaran 2018/2019.

Banyak sekali ahli yang mendefinisikan Higher Order Thinking Skills (HOTS) atau berpikir tingkat tinggi dengan pendekatan dan sudut pandang yang berbeda-beda. Resnick (1987, p. 44) mengemukakan bahwa HOTS sulit untuk didefinisikan, tetapi mudah dikenali melalui ciri-cirinya. Lebih lanjut, Resnick (Resnick, 1987) mengungkapkan beberapa ciriciri dari HOTS yaitu: 1) non-algoritmik, artinya langkah-langkah tindakan tidak dapat sepenuhnya ditentukan di awal; 2) kompleks, artinya langkah-langkah tidak dapat dilihat/ditebak secara langsung dari sudut pandang tertentu; 3) menghasilkan banyak solusi; 4) melibatkan perbedaan pendapat dan interpretasi; 5) melibatkan penerapan kriteria jamak; 6) melibatkan ketidakpastian; 7) menuntut kemadirian dalam proses berpikir; 8) melibatkan pemaknaan yang mengesankan; dan 9) memerlukan kerja keras (effortfull). Berbagai karakteristik atau ciri-ciri tersebut dapat diidentifikasi dalam aktivitas pembelajaran yang melibatkan berbagai tingkatan proses berpikir (thinking process level).

Thomas \& Thorne (2009) menyatakan bahwa berpikir tingkat tinggi menuntut seseorang untuk melakukan sesuatu terhadap fakta, yaitu memahaminya, menyimpulkannya, menghubungkannya dengan fakta dan konsep lain, mengkategorikan, memanipulasi, menempatkan fakta secara bersama-sama dalam cara-cara baru, dan menerapkannya dalam mencari solusi dari masalah. Senada dengan pendapat tersebut, Lewis \& Smith (1993) menyatakan bahwa berpikir tingkat tinggi terjadi ketika seseorang memperoleh informasi baru dan disimpan dalam memori dan mengaitkan dan atau menata ulang dan memperluas informasi tersebut untuk mencapai tujuan atau menemukan kemungkinan jawaban dalam kondisi yang membingungkan. Berdasarkan pendapat kedua ahli tersebut secara ringkas dapat disimpulkan bahwa HOTS menuntut adanya proses berpikir yang lebih kompleks dalam menghadapi situasi atau memecahkan suatu masalah. 
Mengingat tidak ada definisi pasti mengenai HOTS, sebagian ahli mengaitkan HOTS dengan berbagai keterampilan berpikir yang dapat dilakukan oleh setiap individu. Keterampilan-keterampilan berpikir yang dapat dikategorikan sebagai HOTS menurut para ahli diantaranya adalah keterampilan berpikir kritis dan berpikir kreatif (Conklin \& Williams, 2011, p. 14; King, Goodson, \& Rohani, 2011, p. 1; Krulik \& Rudnick, 1999; Presseisen, 2001), pemecahan masalah (Presseisen, 2001), berpikir logis, reflektif, dan metakognitif (King et al., 2011), dan pengambilan keputusan (Presseisen, 2001). Keterampilan-keterampilan tersebut bukanlah istilah asing dalam proses pembelajaran, bahkan telah menjadi sasaran dan bagian dari tujuan pembelajaran disetiap mata pelajaran.

Jika kita cermati kembali terkait proses kognitif yang masuk kategori HOTS yaitu menganalisis, mengevaluasi, dan mencipta, maka kita dapat mengkategorikan bahwa menganalisis dan mengevaluasi merupakan bagian dari berpikir kritis, sedangkan mencipta merupakan bagian dari berpikir kreatif. Menganalisis dan mengevaluasi merupakan bagian dari berpikir kritis didasarkan pada penjabaran definisi berpikir kritis yaitu sebagai proses melakukan penilaian berdasarkan bukti (Eggen \& Kauchak, 2012), menganalisis argumen, mengenali kesenjangan, dan menyimpulkan berdasarkan bukti (Arends \& Kilcher, 2010). Sedangkan mencipta dapat dianggap sebagai bagian dari berpikir kreatif sesuai dengan pendapat para ahli bahwa berpikir kreatif merupakan proses untuk menghasilkan produk/ide/sesuatu yang baru (Arends \& Kilcher, 2010; Krulik \& Rudnick, 1999; Presseisen, 2001). Dengan demikian jika kita buat keterkaitan antara aspek berpikir kritis dan kreatif, dimensi proses kognitif dan dimensi pengetahuan, maka HOTS dapat diringkas seperti Tabel 2.

Tabel 2. Penjabaran HOTS Berdasarkan Keterkaitan antar Dimensi

\begin{tabular}{|c|c|c|c|c|}
\hline Aspek & $\begin{array}{l}\text { Dimensii } \\
\text { Proses } \\
\text { Kognitif }\end{array}$ & $\begin{array}{c}\text { Sub Dimensi } \\
\text { Proses Kognitif }\end{array}$ & $\begin{array}{c}\text { Dimensi } \\
\text { Pengetahuan }\end{array}$ & HOTS \\
\hline \multirow{5}{*}{$\begin{array}{l}\text { Berpikir } \\
\text { Kritis } \\
\text { Matematis }\end{array}$} & \multirow{3}{*}{$\begin{array}{l}\text { Menganal } \\
\text { isis }\end{array}$} & Membedakan & \multirow{6}{*}{$\begin{array}{l}\text { Konseptual } \\
\text { Prosedural } \\
\text { Metakognisi }\end{array}$} & $\begin{array}{lr}\text { Membedakan } & \text { konsep } \\
\text { Membedakan } & \text { prosedur } \\
\text { Membedakan metakognisi }\end{array}$ \\
\hline & & Mengorganisasi & & $\begin{array}{lr}\text { Mengorganisasi } & \text { konsep } \\
\text { Mengorganisasi } & \text { prosedur } \\
\text { Mengorganisasi metakognisi }\end{array}$ \\
\hline & & Mengatribusi & & $\begin{array}{l}\text { Mengatribusi } \\
\text { Mengatribusi } \\
\text { mengatribusi metakognisi }\end{array}$ \\
\hline & \multirow{2}{*}{$\begin{array}{l}\text { Mengeval } \\
\text { uasi }\end{array}$} & Memeriksa & & $\begin{array}{ll}\text { Memeriksa konsep Memeriksa } \\
\text { prosedur } & \text { Memeriksa } \\
\text { metakognisi } & \\
\end{array}$ \\
\hline & & Mengkritisi & & $\begin{array}{l}\text { Mengkritisi } \\
\text { Mengkritisi } \\
\text { Mengkritisi metakognisi }\end{array}$ \\
\hline Berpikir & Mencipta & Merumuskan & & Merumuskan konsep \\
\hline
\end{tabular}




\begin{tabular}{|c|c|c|c|c|}
\hline Aspek & $\begin{array}{l}\text { Dimensii } \\
\text { Proses } \\
\text { Kognitif }\end{array}$ & $\begin{array}{l}\text { Sub Dimensi } \\
\text { Proses Kognitif }\end{array}$ & $\begin{array}{l}\text { Dimensi } \\
\text { Pengetahuan }\end{array}$ & HOTS \\
\hline \multirow[t]{3}{*}{$\begin{array}{c}\text { Kreatif } \\
\text { Matematis }\end{array}$} & & & & $\begin{array}{l}\text { Merumuskan prosedur } \\
\text { Merumuskan metakognisi }\end{array}$ \\
\hline & & Merencanakan & & $\begin{array}{lr}\text { Merencanakan } & \text { konsep } \\
\text { Merencanakan } & \text { prosedur } \\
\text { Merencanakan metakognisi }\end{array}$ \\
\hline & & Memproduksi & & $\begin{array}{lr}\text { Memproduksi } & \text { konsep } \\
\text { Memproduksi } & \text { prosedur } \\
\text { Memproduksi metakognisi }\end{array}$ \\
\hline
\end{tabular}

Berdasarkan Tabel 2 tentang penjabaran HOTS berdasarkan keterkaitan antar dimensi yaitu dimensi kognitif taksonomi Bloom dengan dimensi pengetahuan tertinggi seperti yang ada pada Kurikulum 2013 di Indonesia, maka dapat disimpulkan bahwa kemampuan berpikir matematika tingkat tinggi itu mencakup kemampuan berpikir kritis dan kreatif matematik.

Terdapat beberapa definisi berpikir kritis yang dikemukakan oleh para ahli. Huitt (1998, p. 4) mengemukakan bahwa Critical thinking is disciplined mental activity of making judgments that can guide the development of beliefs and taking actions. Sedangkan Norris (Fowler, 2001, p. 1) medefinisikan berpikir kritis sebagai pengambilan keputusan secara rasional apa yang diyakini dan dikerjakan. Kedua definisi tersebut menunjukkan bahwa berpikir kritis berarah pada pengambilan keputusan mengenai tindakan dan keyakinan yang akan diambil. Proses pengambilan keputusan tersebut, menurut Moore dan Parker (Fowler, 2001) dilakukan secara hati-hati dan tidak tergesa-gesa.

Menurut Ennis (1996, p. 4) berpikir kritis didefinisikan sebagai cara berpikir reflektif dan beralasan yang difokuskan pada pengambilan keputusan tentang apa yang harus diyakini dan dikerjakan. Reflektif artinya mempertimbangkan atau memikirkan kembali segala sesuatu yang dihadapinya sebelum mengambil keputusan. Beralasan artinya memiliki keyakinan dan pandangan yang didukung oleh bukti yang tepat, aktual, cukup, dan relevan. Sejalan dengan pendapat Ennis tersebut, Sukmadinata dan Syaodih (2004) mengatakan bahwa berpikir kritis adalah suatu kecakapan nalar secara teratur, kecakapan sistematis dalam menilai, memecahkan masalah, menarik keputusan, memberikan keyakinan, menganalisis asumsi dan pencarian ilmiah.

Pengembangan kemampuan berpikir kritis matematik di dalam kelas (sekolah) mulai dicetuskan oleh Harlod Fawcett pada tahun 1938 (Hendrayana, 2008, p. 16). Pengembangan berpikir kritis yang dilakukan oleh Fawcett adalah mencoba mengajarkan kemampuan berpikir kritis yang aktivitasnya seperti: membandingkan, mengklasifikasikan, membuat kategori, mengurutkan, memvalidasi, membuktikan, mengaitkan, menganalisis, mengevaluasi dan membuat pola, yang aktivitas-aktivitasnya dirangkai secara 
berkesinambungan (Hendrayana, 2008). Jauh setelah idenya Fawcett, baru pada tahun 1989, NCTM dalam buku tahunannya "Curriculum and Evaluation Standards" menyarankan untuk mengembangkan kemampuan berpikir di dalam kelas. Setelah itu, mulai banyak penelitian dan pengembangan berpikir kritis dalam bidang matematika baik itu ditingkat internasional maupun nasional.

Berdasarkan pendapat-pendapat yang telah dikemukakan tersebut, penulis berpendapat bahwa berpikir kritis matematik adalah proses kemampuan siswa untuk mengidentifikasi asumsi yang digunakan, merumuskan pokok-pokok permasalahan, menentukan akibat dari suatu ketentuan yang diambil, mendeteksi adanya bias berdasarkan pada sudut pandang yang berbeda, mengungkap konsep, teorema atau definisi yang digunakan, serta mengevaluasi argumen yang relevan dalam menyelesaikan suatu masalah. Kemampuan berpikir kritis matematik ini mencakup kemampuan menganalisis dan memeriksa kesahihan suatu argumen, menarik induksi dari serangkain informasi/data, mengidentifikasi kecukupan data suatu masalah, memilih cara penyelesaian yang terbaik dari alternatif-alternatif cara penyelesaian yang ada, mengidentifikasi karakteristik penyelesaian suatu masalah, dan mengevaluasi proses penyelesaian masalah. Oleh karena itu indikator kemampuan berpikkir kritis yang digunakan peneliti yaitu kemampuan mengidentifikasi, menjastifikasi konsep, dan memberikan evaluasi subjek dan objek matematis.

Secara umum Bills dan Genasi (2003) mendefinisikan kreativitas sebagai "the capacity to challenge the existing order of things, by deliberately forcing ourselves out of our usual way of thinking, to see the status quo from a new and enlightening perspective, to form new ideas and find practical ways to implement change in the light of fresh insights." Simpson (Munandar, 2002) mengungkapkan pula bahwa kemampuan kreatif merupakan inisiatif yang ditunjukkan seseorang dengan kekuatannya untuk berhenti dari cara berpikir biasa. Hal ini berarti kreativitas dikaitkan dengan kekuatan untuk memaksa diri sendiri keluar dari cara berpikir yang biasa digunakan untuk menghasilkan ide-ide baru.

Perkembangan era 4.0 revolusi yang semakin pesat menuntut masyarakat luas untuk memiliki kemampuan berpikir kreatif secara matematis. Salah satu upaya untuk meningkatkan kemampuan berpikir kreatif adalah melalui pendidikan yang berkualitas (Maskur et al., 2020). Kreativitas menjadi sebuah proses mental yang melibatkan pengembangan ide atau konsep baru, atau penggabungan antara ide-ide atau konsepkonsep yang ada. Tannenbaum (McFadzean, 1998, p. 309) menyatakan bahwa "creativity is a useful process because it improves communication, promotes learning and the exploration of the problem, and helps to develop new ideas, solutions and/or alternatives". 
Selanjutnya menurut Haefele (Munandar, 2002) kreativitas adalah kemampuan untuk membuat kombinasi-kombinasi baru yang mempunyai makna sosial. Pendapat-pendapat tersebut menyatakan bahwa kreativitas dapat pula dilihat sebagai suatu proses menghasilkan ide, solusi atau pilihan-pilihan baru yang bermanfaat dan bermakna. Proses tersebut dapat pula berupa penggabungan dari ide-ide atau konsep-konsep yang sudah ada.

Selanjutnya Guilford (Munandar, 2002) menciptakan suatu teori intelegensi yang memiliki tiga dimensi atau matra yaitu materi, produk, dan operasi. Guilford membedakan lima kategori operasi yaitu kognisi, ingatan, berpikir divergen, berpikir konvergen, dan evaluasi. Menurut Guilford berpikir divergen juga disebut berpikir kreatif yang memberikan bermacam kemungkinan jawaban berdasarkan informasi yang diberikan, dengan penekanan pada keragaman kuantitas dan kesesuaian. Beberapa faktor yang termasuk berpikir divergen adalah fluency, flexibility, dan elaboration. Terdapat tiga jenis fluency (kelancaran atau kefasihan), yaitu ideational fluency, associational fluency, dan expressional fluency. Ideational fluency adalah kecepatan membangun ide-ide berdasarkan kuantitas; associational fluency adalah menyelesaikan keterkaitan, dapat juga diterapkan dalam mengkonstruksi analogi; dan expressional fluency adalah kemampuan untuk mengkonstruksi kalimat. Terdapat dua jenis flexibility (keluwesan atau kelenturan) yaitu spontaneous flexibility yang berarti kemampuan untuk beralih ke jawaban lain tanpa harus diarahkan dan adaptive flexibility yang berarti jawaban yang orisinil. Elaboration (keterperincian atau elaborasi) adalah hasil dari berbagai implikasi. Sedangkan dalam Torrance Tests of Creative Thinking (Almeida, Prieto, Ferrando, Oliveira, \& Ferrándiz, 2008), terdapat empat faktor yaitu fluency, flexibility, originality, and elaboration. Berdasarkan beberapa pengertian tersebut, maka aspek berpikir kreatif meliputi fluency, flexibility, elaboration, dan originality dengan penjelasan dari masing-masing aspek tersebut sebagai berikut. a) fluency (keterampilan berpikir lancar) adalah kemampuan membangun banyak ide secara mudah. Ciri-cirinya, mencetuskan banyak gagasan, jawaban, penyelesaian masalah, atau pertanyaan; memberikan banyak cara atau saran untuk melakukan berbagai hal; selalu memikirkan lebih dari satu jawaban, b) flexibility (keterampilan berpikir luwes) adalah kemampuan membangun ide yang beragam. Dalam pemecahan masalah, keluwesan terkait dengan kemampuan untuk mencoba berbagai pendekatan dalam menyelesaikan suatu masalah. Ciri-cirinya, menghasilkan gagasan, jawaban, atau pertanyaan yang bervariasi; dapat melihat masalah dari sudut pandang yang berbeda-beda; mampu mengubah cara pendekatan atau cara pemikiran, c) elaboration (keterampilan merinci) adalah kemampuan memperkaya dan mengembangkan suatu gagasan atau produk; menambahkan atau memperinci secara detil dari suatu objek, gagasan, atau situasi sehingga lebih menarik. d) Originality (keterampilan berpikir orisinil) 
adalah kemampuan melahirkan ungkapan yang baru dan unik, memikirkan cara yang tidak lazim untuk mengungkapkan diri, mampu membuat kombinasi yang tidak lazim dari bagian-bagian atau unsur-unsur.

Berdasarkan pendapat-pendapat di atas, penulis berpendapat bahwa berpikir kreatif adalah kemandirian, keaslian, kelancaran, kelenturan, elaborasi, dan evaluasi terhadap keterperincian respon siswa dalam menggunakan konsep-konsep, prosedur dan skill dalam matematika. Kemampuan tersebut meliputi kompetensi dapat mengajukan ide-ide baru berdasarkan situasi yang diberikan, melengkapi data dalam menyusun masalah, menggambar atau representasi matematik sesuai dengan karekteristik, menemukan beberapa cara yang mungkin benar, menyusun kemungkinan-kemungkinan penyelesaian suatu masalah, menyusun pola, dan menentukan banyaknya unsur pada pola tertentu serta kesimpulan (Septian \& Rizkiandi, 2017).

Dari beberapa ciri-ciri kemampuan berpikir kreatif yang telah diungkapkan di atas maka aspek yang diukur dari kemampuan berpikir kreatif matematik pada penelitian ini adalah kemampuan mencetuskan ide atau gagasan secara mudah (kelancaran/fulency); membangun ide yang beragam (keluwesan/flexibility); merinci secara detil langkahlangkah penyelesaian (elaborasi/elaboration); dan mencetuskan gagasan yang baru dan unik (keaslian/originality).

\section{METODE PENELITIAN}

Jenis penelitian yang akan dilakukan termasuk kepada jenis penelitian deskriptif, karena tujuan utama dari penelitian ini adalah untuk mendeskripsikan distribusi kemampuan berpikir matematik tingkat tinggi siswa Sekolah Menengah Atas Negeri tahun pelajaran 2018/2019. Hal ini sesuai dengan pendapat Sukmadinata (2012) yang menyatakan bahwa penelitian deskriptif merupakan jenis penelitian yang bertujuan untuk mendeskripsikan fenomena-fenomena yang ada, baik fenomena alamiah maupun fenomena buatan manusia. Fenomena itu dapat berupa bentuk, aktivitas, perubahan, karakteristik, hubungan, kesamaan, dan perbedaan antara fenomena yang satu dengan fenomena lainnya.

Metode penelitian yang digunakan pada penelitian ini adalah metode deskriptif, yaitu dengan cara hanya memberikan soal tes kemampuan berpikir matmatik tingkat tinggi saja kepada subjek penelitian. Hal ini sesuai dengan pendapat Nazir dalam Rahmawati (2016) yang menyatakan bahwa metode deskriptif merupakan suatu metode dalam meneliti status sekelompok manusia, suatu objek, suatu set kondisi, suatu sistem pemikiran ataupun suatu kelas peristiwa pada masa sekarang. Tujuan dari penggunaan metode penelitian ini adalah untuk membuat deskripsi, gambaran, atau lukisan secara sistematis, faktual dan 
akurat mengenai fakta-fakta, sifat-sifat serta hubungan antarfenomena yang diselidiki. Tahapan atau alur penelitian pada penelitian tergambar seperti pada Gambar 1 berikut:

Tahapan atau alur penelitian pada penelitian tergambar seperti pada Gambar 1 berikut:

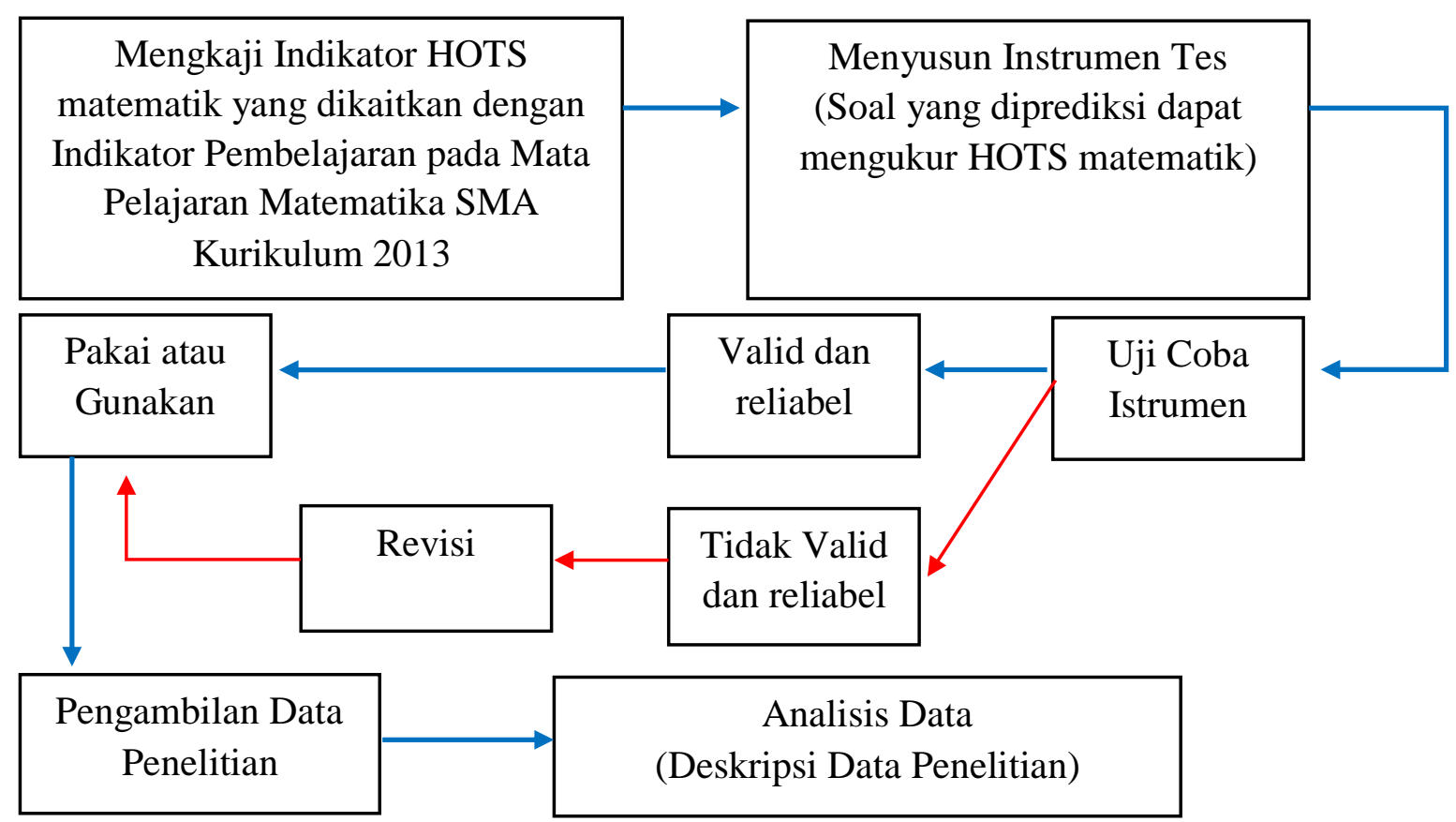

Gambar 1. Alur rancangan penelitian

Populasi penelitian ini adalah seluruh siswa Sekolah Menengah Atas Negeri (SMAN 1 s.d. SMAN 10) Kota Tasikmalaya baik kelas X, kelas XI, dan kelas XII, kisaran usianya 16-18 tahun. Teknik pengambilan sampel pada penelitian ini menggunakan teknik probability sampling yaitu Proportionate Stratified Random Sampling, dengan mengambil 2 kelas setiap sekolah. Selanjutnya dilaksanakan tes kemampuan HOTS, diteruskan dengan pengolahan dan analisis data dengan menggunakan program SPSS dan akhirnya disusun laporan hasil penelitian yang intinya memberikan gambaran tentang kemampuan HOT di Sekolah Menengah Atas Negeri (SMAN) Kota Tasikmalaya. Desain penelitiannya sebagai berikut:

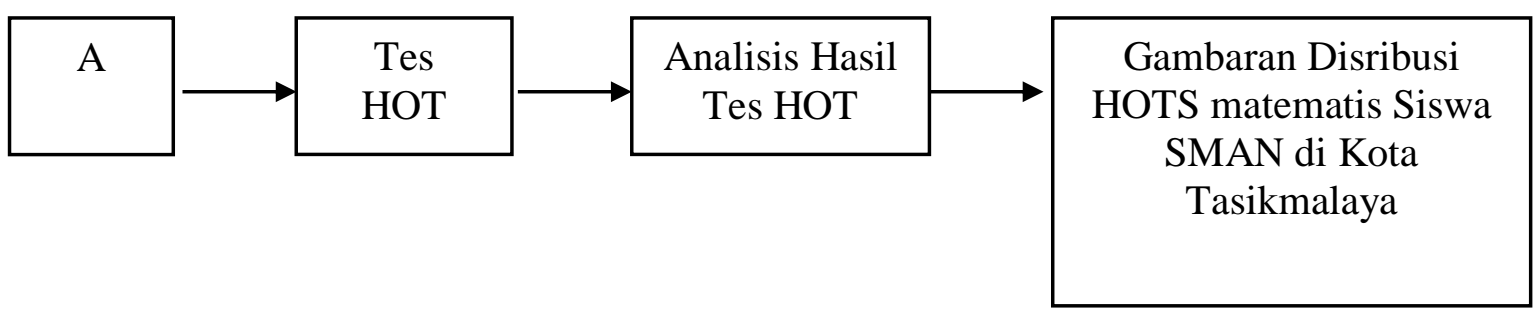

Gambar 2. Desain Penelitian

Skor yang diperoleh dari hasil tes untuk mengukur HOTS matematis siswa kemudian ditaransformasikan ke dalam skor maksimal ideal 100 atau dirubah ke dalam 
skala 100 (berdasarkan permendikbud nomor 23). Selanjutnya disajikan menggunakan teori statistika deskriptif, untuk menghitung ukuran-ukuran statistiknya serta penyusunan tabel statistik. Pengujian hipotesisya menggunakan kategori penguasaan kemampuan .HOTS matematis siswa dari Depdiknas yaitu seperti pada Tabel 3. berikut:

Tabel 3. Kriteria Kategori Penguasaan Kemampuan HOT Siswa SMA

\begin{tabular}{|c|c|c|}
\hline Interval & Penguasaan & Kategori Tingkat Penguasaan \\
\hline $85 \leq$ & $X \leq 100$ & Amat Baik \\
\hline $70 \leq$ & $X \quad<85$ & Baik \\
\hline $50 \leq$ & $X<70$ & Cukup baik \\
\hline $0 \leq$ & $X<50$ & Kurang baik \\
\hline
\end{tabular}

\section{HASIL DAN PEMBAHASAN}

Proses Pengumpulan data penelitian diawali dengan melakukan koordinasi kepada pihak Sekolah, dan berdasarkan koordinasi tersebut, maka pengambilan data penelitian dilakukan mulai tanggal 12 sampai dengan 16 Agustus 2019. Kelas yang menjadi sampel penelitian adalah kelas XII, dengan asumsi bahwa pada kelas XII materi pembelajaran matematika di SMA 80\% sudah mereka peroleh atau sudah pernah belajar. Data Hasil penelitian yang telah diperoleh adalah sebagai berikut:

Tabel 4. Data Jumlah Sampel Penelitian

\begin{tabular}{cccc}
\hline No & Nama Sekolah & Banyak Sampel & Persentase \\
\hline 1 & SMAN A TASIKMALAYA & 64 & $9,065 \%$ \\
\hline 2 & SMAN B TASIKMALAYA & 74 & $10,482 \%$ \\
\hline 3 & SMAN C TASIKMALAYA & 77 & $10,907 \%$ \\
\hline 4 & SMAN D TASIKMALAYA & 72 & $10,198 \%$ \\
\hline 5 & SMAN E TASIKMALAYA & 68 & $9,632 \%$ \\
\hline 6 & SMAN F TASIKMALAYA & 80 & $11,331 \%$ \\
\hline 7 & SMAN G TASIKMALAYA & 65 & $9,207 \%$ \\
\hline 8 & SMAN H TASIKMALAYA & 78 & $11,048 \%$ \\
\hline 9 & SMAN I TASIKMALAYA & 65 & $9,207 \%$ \\
\hline 10 & SMAN J TASIKMALAYA & 63 & $8,924 \%$ \\
\hline \multicolumn{7}{c}{ Total } & 706 & $100 \%$ \\
\hline
\end{tabular}

Berdasarkan data pada Tabel 4. maka total jumlah sampel penelitian adalah 706 orang yang berasal dari sepuluh SMA yang ada di Kota Tasikmalaya. Sampel terbanyak berasal dari SMA Negeri F Kota Tasikmalaya yaitu 80 orang atau 11,331\% dan sampel paling sedikit berasal dari SMA Negeri J yaitu 63 orang atau 8,924\%.

Setelah diberikan soal tes untuk mengukur kemampuan berpikir tingkat tinggi (berpikir kritis dan berpikir kreatif), maka diperoleh hasil dari tes kemampuan berpikir matematika tingkat tinggi (High Order Thinking) sebagai berikut: 
Tabel 5. Data Rata-Rata Hasil Tes Kemampuan High Order Thinking (HOT)

\begin{tabular}{clcc}
\hline No & Nama Sekolah & $\begin{array}{c}\text { Kemampuan } \\
\text { Berpikir Kritis }\end{array}$ & $\begin{array}{c}\text { Kemampuan } \\
\text { Berpikir Kreatif }\end{array}$ \\
\hline 1 & SMAN A TASIKMALAYA & 17,16 & 17,03 \\
\hline 2 & SMAN B TASIKMALAYA & 15,07 & 14,96 \\
\hline 3 & SMAN C TASIKMALAYA & 15,42 & 15,23 \\
\hline 4 & SMAN D TASIKMALAYA & 15,15 & 14,93 \\
\hline 5 & SMAN E TASIKMALAYA & 14,97 & 14,68 \\
\hline 6 & SMAN F TASIKMALAYA & 16,96 & 17,15 \\
\hline 7 & SMAN G TASIKMALAYA & 15,45 & 14,55 \\
\hline 8 & SMAN H TASIKMALAYA & 14,95 & 15,19 \\
\hline 9 & SMAN I TASIKMALAYA & 15,25 & 13,80 \\
\hline 10 & SMAN J TASIKMALAYA & 13,76 & 15,19 \\
\hline & Rata-rata & 15,41 &
\end{tabular}

Berdasarkan data pada Tabel 5. maka diperoleh hasil rata-rata kemampuan berpikir kritis adalah 15,41 dan rata-rata kemampuan berpikir kreatif adalah 15.19. Apabila dilihat berdasarkan rata-rata tersebut dapat disimpulkan bahwa rata-rata kemampuan berpikir kreatif dan kemampuan kritis tidak jauh berbeda. Rata-rata kemampuan berpikir kritis paling tinggi diperoleh oleh SMA Negeri A dengan skor rata-rata 17,16 dari rata-rata skor maksimal ideal 20, dan rata-rata kemampuan berpikir kritis paling rendah diperoleh oleh SMA Negeri J dengan skor rata-rata kemampuan berpikir kritis 13,76 dari rata-rata skor maksimal ideal 20. Sedangkan skor rata-rata kemampuan berpikir kritis paling tinggi diperoleh oleh SMA Negeri F dengan rata-rata skor kemampuan berpikir kreatif 17,15 dari rata-rata skor maksimal ideal 20 dan rata-rata kemampuan berpikir kritis paling rendah diperoleh oleh SMA Negeri J dengan rata-rata skor kemampuan berpikir kreatif 13,,40 dari rata-rata skor maksimal ideal 20.

Apabila kedua kemampuan tersebut digabungkan maka akan terbentuk kemampuan berpikir matematika tingkat tinggi (High Order Thingking Skill of Matematics), Berdasarkan hasil peneltian tersebut maka diperoleh hasil seperti berikut:

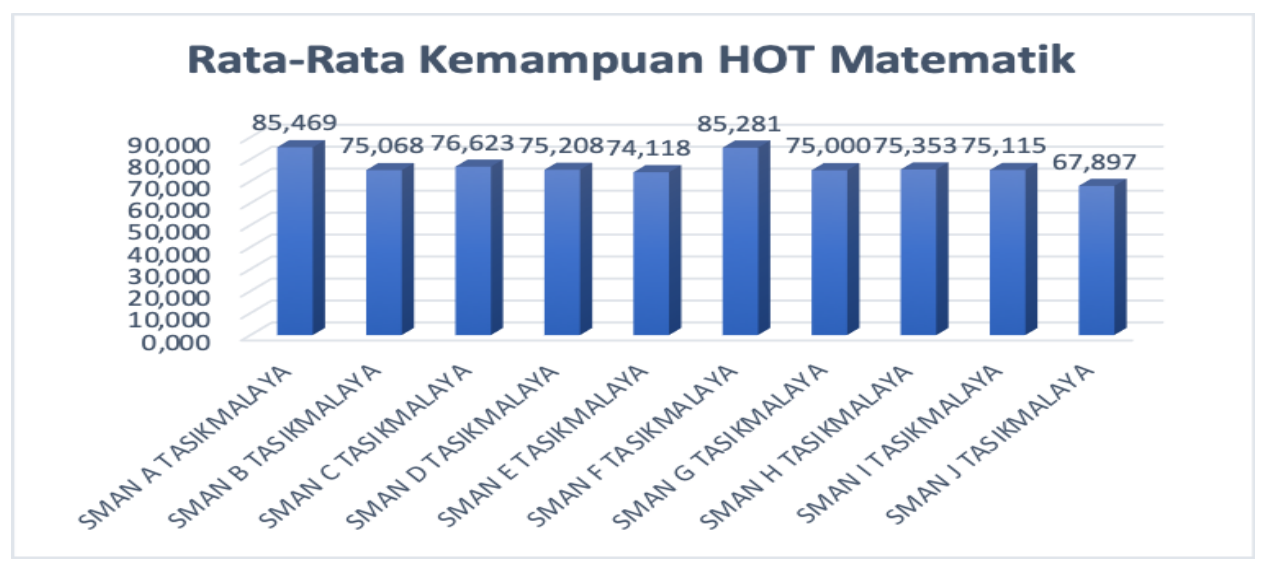

Gambar 3. Diagram Distribusi Rata-Rata Kemampuan HOT Matematika Siswa pada Setiap Sekolah 
Berdasarkan data pada Gambar 3 diperoleh gambaran kemampuan HOT matematika siswa pada setiap Sekolah, rata-rata kemampuan HOT matematik siswa paling tinggi diperoleh oleh SMA Negeri A dengan skor 85,469 dan rata-rata kemampuan HOT matematik siswa paling rendah doperoleh oleh SMA Negeri J Kota Tasikmalaya. Apabila kemampuan tersebut dikategorikan berdasarkan kategori Penguasaan Kemampuan HOT Siswa SMA, maka diperoleh data sebagai berikut.

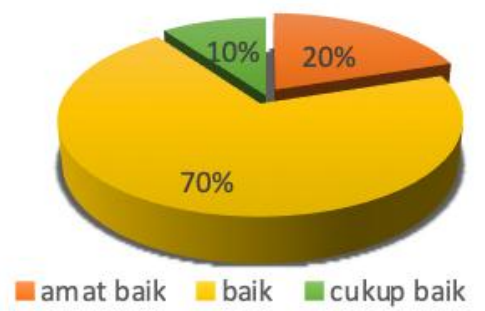

Gambar 4. Diagram Lingkaran Kategori Penguasaan dan Persentase Kemampuan HOT Matematik Siswa di SMAN Kota Tasikmalaya

Berdasarkan data pada Gambar 4, maka untuk menjawab rumusan masalah dengan pertanyaan "bagaimana distribusi kemampuan berpikir matematik tingkat tinggi siswa Sekolah Menengah Atas Negeri di Kota Tasikmalaya pada tahun pelajaran 2018/2019?", maka diperoleh distribusi kemampuan berpikir matematik tingkat tinggi (High Order Thingking Skill of Matematics) pada siswa Sekolah Menengah Atas Negeri di Kota Tasikmalaya tahun pelajaran 2018/2019 sebagai berikut: 1) kemampuan HOTS matematik dengan kategori amat baik diperoleh oleh 2 Sekolah, yaitu SMAN A dan SMAN F atau 20\% dari seluruh Sekolah SMA Negeri yang ada di Kota Tasikmalaya, 2) kemampuan HOTS matematik dengan kategori baik diperoleh oleh 7 Sekolah, yaitu SMAN B, SMAN C, SMAN D, SMAN E, SMAN G, SMAN H dan SMAN 1 atau 70\% dari seluruh Sekolah SMA Negeri yang ada di Kota Tasikmalaya, 3) kemampuan HOTS matematik dengan kategori cukup baik diperoleh oleh 1 Sekolah, yaitu SMAN J atau 10\% dari seluruh Sekolah SMA Negeri yang ada di Kota Tasikmalaya.

Sedangkan untuk menjawab rumusan masalah nomor 2 dengan pertanyaan "apakah terdapat hubungan antara kemampuan berpikir kritis matematis dengan kemampuan berpikir kreatif matematika siswa Sekolah Menengah Atas Negeri di Kota Tasikmalaya tahun pelajaran 2018/2019" maka dilakukan uji korelasi bivariat dengan menggunakan software IBM Statistik 2.1, dan hasilnya adalah sebagai berikut. 
Tabel 6. Korelasi Pearson antara Kemampuan Berpikir Kritis dan Kreatif Matematis

\begin{tabular}{|c|c|c|c|}
\hline \multicolumn{4}{|c|}{ Correlations } \\
\hline & & & Kemampuan \\
\hline & & Kemampuan & Berpikir \\
\hline & & Berpikir Kritis & Kreatif \\
\hline \multirow{3}{*}{$\begin{array}{l}\text { Kemampuan Berpikir } \\
\text { Kritis }\end{array}$} & Pearson Correlation & 1 & $0,283^{* *}$ \\
\hline & Sig. (2-tailed) & & 0,000 \\
\hline & $\mathrm{N}$ & 706 & 706 \\
\hline \multirow{3}{*}{$\begin{array}{l}\text { Kemampuan Berpikir } \\
\text { Kreatif }\end{array}$} & Pearson Correlation & $0,283^{* *}$ & 1 \\
\hline & Sig. (2-tailed) & 0,000 & \\
\hline & $\mathrm{N}$ & 706 & 706 \\
\hline
\end{tabular}

Berdasarkan Tabel 6, maka diketahui nilai Sig. (2-tailed) adalah 0,000 hal ini menunjukkan bahwa nilai Sig. (2-tailed) yaitu $0,000<0,05$ yang berarti terdapat hubungan yang signifikan antara kemampuan berpikir kritis matematis siswa dengan kemampuan berpikir kreatif matematik siswa Sekolah Menengah Atas Negeri di Kota Tasikmalaya tahun pelajaran 2018/2019. Sedangkan untuk derajat hubungannya diperoleh koefisien korelasi sebesar 0,283 atau berada pada kategori rendah.

\section{KESIMPULAN}

Berdasarkan hasil pengolahan dan analis data yang telah dilakukan, maka kesimpulan hasil penelitian menunjukkan bahwa kemampuan HOTS matematika dari seluruh siswa di SMAN se-Kota Tasikmalaya, sebagian kecil siswa di antaranya berada pada kategori sangat baik, sebagian besar siswa berada pada kategori baik, dan sebagian kecil siswa lainnya berada pada kategori cukup baik. Di samping itu dapat disimpulkan pula bahwa kemampuan berpikir kritis matematis berhubungan secara signifikan dengan kemampuan berpikir kreatif matematik siswa SMAN di Kota Tasikmalaya tahun pelajaran $2018 / 2019$.

\section{REFERENSI}

Agustyaningrum, N. (2015). Mengembangkan keterampilan berpikir tingkat tinggi dalam pembelajaran matematika SMP. Pythagoras: Jurnal Program Studi Pendidikan Matematika, 4(1), 39-46.

Almeida, L. S., Prieto, L. P., Ferrando, M., Oliveira, E., \& Ferrándiz, C. (2008). Torrance Test of Creative Thinking: The question of its construct validity. Thinking Skills and Creativity, 3(1), 53-58. https://doi.org/10.1016/j.tsc.2008.03.003

Anderson, L. W., Krathwohl, D. R., Airasian, P. W., Cruikshank, K. A., Mayer, R. E., Pintrich, P. R., ... Wittrock, M. C. (Eds.). (2001). A taxonomy for learning, teaching, and assessing : a revision of Bloom's taxonomy of educational objectives. New York, NY: Addison Wesley Longman. 
Arends, R. I., \& Kilcher, A. (2010). Teaching for student learning: Becoming an accomplished teacher (1st ed.). https://doi.org/10.4324/9780203866771

Bills, T., \& Genasi, C. (2003). Creative business: Achieving your goals through creative thinking and action. New York, NY: Palgrave Macmillan.

Conklin, W., \& Williams, R. B. (2011). Higher-order thinking skills to develop 21st century learners. Huntington Beach, CA: Shell Education.

Eggen, P. D., \& Kauchak, D. (2012). Strategies and models for teachers: Teaching content and thinking skills (S. Wahono, Trans.). https://doi.org/10.1177/019263658807250832

Ennis, R. H. (1996). Critical Thinking Dispositions: Their Nature and Assessability. Informal Logic, 18(2), 165-182. https://doi.org/10.22329/il.v18i2.2378

Finish National Agency for Educaition. (2003). Lukiokoulutuksen opetussuunnitelman perusteet. Helsinki, Finland: Author.

Fisher, R. (2006). Thinking skills. In T. Cremin \& C. Burnett (Eds.), Learning to teach in the primary school (4th ed.). London, United Kingdom: Routledge.

Fowler, B. (2001). Critical thinking across the curriculum project. Bloom's taxonomy and critical thinking. Longview Community College.

Hendrayana, A. (2008). Pengembangan multimedia interaktif untuk meningkatkan kemampuan berpikir kritis dan kreatif siswa SMP dalam matematika. Universias Pendidikan Indonesia.

Hidayati, A. U. (2017). Melatih keterampilan berpikir tingkat tinggi dalam pembelajaran matematika pada siswa sekolah dasar. TERAMPIL: Jurnal Pendidikan Dan Pebelajaran Dasar, 4(2), 143-156. https://doi.org/10.24042/terampil.v4i2.2222

Huitt, W. (1998). Critical Thinking: An overview educational psychology interactive. Educational Psychology Interactive. Valdosta, GA: Valdosta State University.

King, F. J., Goodson, L., \& Rohani, F. (2011). Higher order thinking skills: Definition, teaching strategies, assessment. Publication of the Educational Services Program, Now Known as the Center for Advancement of Learning and Assessment. Tallahassee, FL: Center for Advancement of Learning and Assessment.

Krulik, S., \& Rudnick, J. A. (1999). Innovative tasks to improve critical and creative thinking skills. In L. Stiff \& F. R. Curcio (Eds.), Developing mathematical reasoning in grades $K-12$ (pp. 138-145). Reston, VA: National Council of Teachers of Mathematics.

Lewis, A., \& Smith, D. (1993). Defining higher order thinking. Theory Into Practice, 32(3), 131-137. https://doi.org/10.1080/00405849309543588

Liu, X. (2009). Essentials of science classroom assessment. Los Angeles, LA: Sage Publications.

Maskur, R., Sumarno, Rahmawati, Y., Pradana, K., Syazali, M., Septian, A., \& Palupi, E. K. (2020). The effectiveness of problem based learning and aptitude treatment interaction in improving mathematical creative thinking skills on curriculum 2013. European Journal of Educational Research, 9(1), 375-383. https://doi.org/10.12973/eu-jer.9.1.375

McFadzean, E. (1998). Enhancing creative thinking within organisations. Management Decision, 36(5), 309-315. https://doi.org/10.1108/00251749810220513

Munandar, U. (2002). Kreativitas dan keberbakatan: Strategi mewujudkan potensi kreatif dan bakat. Jakarta, Indonesia: Gramedia Pustaka Utama.

NCTM. (2000). Principles and Standards for School Mathematics. In School Science and Mathematics (Vol. 47). Retrieved from www.nctm.org

Partnership for 21st Century Skills. (2002). Learning for the 21st century: A report and mile guide for 21 st century skills. Washington, DC. 
Presseisen, B. Z. (2001). Thinking skills: Meanings and models revisited. In A. L. Costa (Ed.), Developing minds: A resource book for teaching thinking (3rd ed.). Alexandria: Association for Supervision and Curriculum Development.

Rahmawati, R. (2016). Tingkat motivasi belajar peserta didik pada mata pelajaran geografi di SMA Kota Bandung. Universitas Pendidikan Indonesia.

Resnick, L. B. (1987). Education and learning to think. National Academy Press.

Septian, A., \& Rizkiandi, R. (2017). Penerapan Model Problem Based Learning ( PBL ) terhadap Peningkatan Kemampuan Berpikir Kreatif. Jurnal Prisma Universitas Suryakancana, VI(1), 1-8.

Somatanaya, A. G., \& Nugraha, D. A. (2018). Pemetaan High Order Thingking (HOTS) Matematis Siswa Sekolah Menengah Pertama Se-Kota Tasikmalaya. TEOREMA: Teori Dan Riset Matematika, 3(2), 187. https://doi.org/10.25157/teorema.v3i2.1170

Sukmadinata, N. S. (2012). Metode penelitian pendidikan. Bandung, Indonesia: Remaja Rosdakarya.

Sukmadinata, N. S., \& Syaodih, E. (2004). Kurikulum dan pembelajaran kompetensi. Bandung, Indonesia: Kesuma Karya.

Thomas, A., \& Thorne, G. (2009). How to increase higher order thinking. Metarie, LA: Center for Development and Learning.

Thompson, T. (2008). Mathematics teachers' interpretation of higher-order thinking in Bloom's taxonomy. International Electronic Journal of Mathematics Education, 3(2), 96-109. 